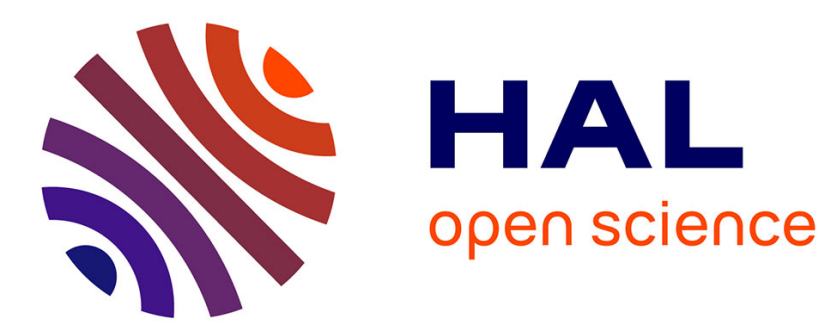

\title{
Interconversion between Möbius chiroptical states sustained by hexaphyrin dynamic coordination
}

\author{
Bernard Boitrel, Stéphane Le Gac
}

\section{To cite this version:}

Bernard Boitrel, Stéphane Le Gac. Interconversion between Möbius chiroptical states sustained by hexaphyrin dynamic coordination. Chemical Communications, 2021, 57 (29), pp.3559-3562. 10.1039/d1cc00741f . hal-03193303

\section{HAL Id: hal-03193303 https://hal.science/hal-03193303}

Submitted on 23 Apr 2021

HAL is a multi-disciplinary open access archive for the deposit and dissemination of scientific research documents, whether they are published or not. The documents may come from teaching and research institutions in France or abroad, or from public or private research centers.
L'archive ouverte pluridisciplinaire HAL, est destinée au dépôt et à la diffusion de documents scientifiques de niveau recherche, publiés ou non, émanant des établissements d'enseignement et de recherche français ou étrangers, des laboratoires publics ou privés. 


\title{
Interconversion between Möbius Chiroptical States Sustained by Hexaphyrin Dynamic Coordination
}

\author{
Bernard Boitrel ${ }^{a}$ and Stéphane Le Gac *a \\ a. Univ Rennes, CNRS, ISCR (Institut des Sciences Chimiques de Rennes)-UMR 6226, \\ Rennes F-35000, France.E-mail: stephane.legac@univ-rennes1.fr. \\ Electronic Supplementary Information (ESI) available: experimental part, NMR and
}

ECD spectra. See DOI: 10.1039/x0xx00000x

Received 00th January 20xx,

Accepted 00th January 20xx

DOI: $10.1039 / x 0 \times x 00000 x$

Harnessing the chiroptical properties of molecular Möbius rings is motivated by fundamental aspects while challenged by synthetic difficulties. Focusing on Möbius aromatic $\mathrm{Zn}$ (II) hexaphyrin complexes, interconversion between two chiral states was achieved through binding and release of an amino ligand (forward/backward stimuli), leading to different chiroptical switching phenomena (amplification, on-off, inversion). The amine either supplies the chirality or behaves as an achiral effector regulating the $\mathrm{Zn}$ (II)-binding of a second (chiral) carboxylato ligand. These results highlight the Möbius [28]hexaphyrin scaffold as an attractive chiral switchable unit.

Chiroptical switches exhibit chiral states interconvertible by a stimulus input (chemical, redox, light...), each state having specific interactions with polarized light leading to changes in the chiroptical spectroscopic response. ${ }^{1}$ Chiroptical switches have spread in many research fields, empowering significant implication in molecular recognition (sensing), information storage, optoelectronic materials, asymmetric catalysis. ${ }^{2}$

In this context, whereas a wide range of (supra)molecular scaffolds supplying various types of stereogenic sources has been developed, it is worth to note that the chirality inherent to the Möbius topology ${ }^{3}$ (Figure 1a) has been scarcely investigated. Harnessing the chiroptical properties of molecular Möbius rings, and more particularly those featuring a $4 n \pi-$ conjugated system giving rise to an aromatic character, ${ }^{4,5}$ remains of high fundamental interest but is challenged by synthetic difficulties. Whereas some scaffolds afford shapepersistent Möbius stereoisomers and thus a fix chirality, ${ }^{6}$ others allow conformational equilibrium between Möbius stereoisomers leading to a dynamic chirality. Some expanded porphyrins belong to both categories, as their native dynamic scaffold can be frozen by coordination chemistry. ${ }^{7,8}$ Focusing on the regular [28] hexaphyrin which is intrinsically dynamic (Figure 1b), 9,10 our group has developed Möbius Zn(II) metalloreceptors exhibiting strong interplay between aromaticity, guest recognition, and chirality transfer (Figure 1c). ${ }^{11}$ These metal complexes are labile with the main advantage that both exogenous ligand binding and conformational isomerism are dynamic processes in solution at room temperature. $P / M$ twist stereoselectivity can thus be readily addressed in situ in mild conditions upon addition of an adequate chiral source, eventually combined to the cooperative action of an achiral effector. ${ }^{11 c, f, g}$ When two chiral sources are simultaneously bound to the metal center, two-fold transfer of chirality of increasing complexity (match-mismatch effects) allow to tune the chiroptical activity of the Möbius $\pi$-system (Figure 1c).11g,12 Pursuing our investigations, herein, we present our results towards chemically controlled, coordination driven, chiroptical switches from Möbius aromatic [28]hexaphyrin 1 (Scheme 1). This compound is functionalized by pentafluorophenyl and 2acetamidophenyl substituents in alternate meso positions, a pattern suitable for both stability purposes and to establish a second sphere of coordination. ${ }^{11 c, 8}$
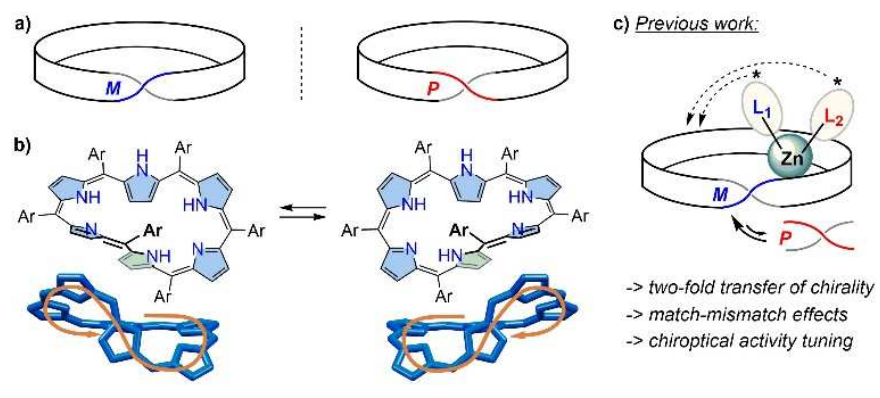

Figure 1. (a) $M$ and $P$ enantiomers of a Möbius ring (singly twisted). (b) Equilibrium between the two enantiomers of a Möbius aromatic [28] hexaphyrin: energy barrier, $c a$. $8 \mathrm{kcal}$. $\mathrm{mol}^{-1}\left(\mathrm{Ar}=\mathrm{C}_{6} \mathrm{~F}_{5}\right) .^{9 \mathrm{~b}, 10}$ (c) Cartoon of a two-fold transfer of chirality in Möbius [28] hexaphyrin metallo-receptors. ${ }^{11 \mathrm{~g}}$

As summarized in Scheme 1, compound $\mathbf{1}$ forms mononuclear $\mathrm{Zn}$ (II) complexes in which the tetrahedral metal ion is bound to 


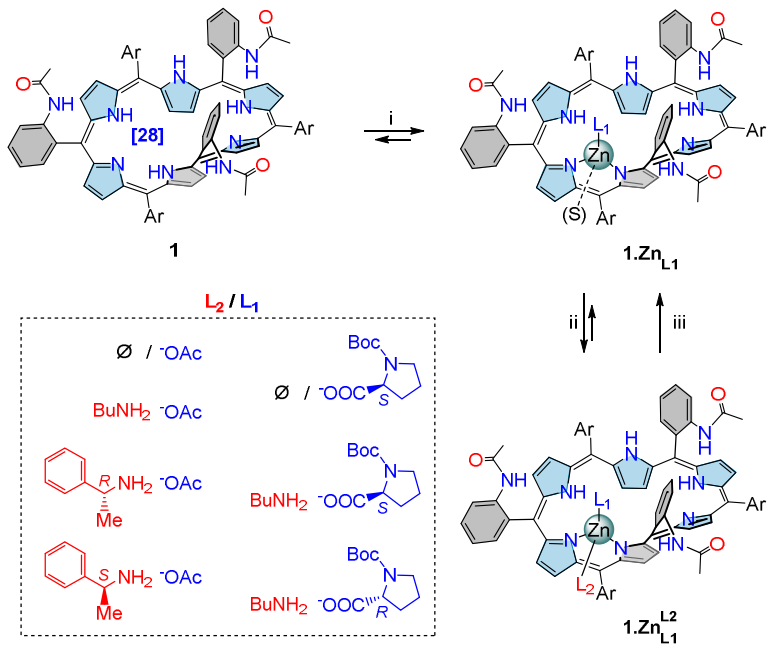

Scheme 1. $\mathrm{Zn}$ (II) metallation of [28] hexaphyrin $1\left(\mathrm{Ar}=\mathrm{C}_{6} \mathrm{~F}_{5}\right)$ in the presence of two different ligands (for the sake of clarity, only one possible isomer [Möbius conformation and 2-acetamidophenyl orientation] is displayed; for $1.2 \mathrm{n}_{\mathrm{L1}}$, '(S)' indicates the likely coordination of methanol; in the name $1 . \mathrm{Zn}_{\mathrm{L1}}{ }^{\mathrm{L}}, \mathrm{L} 1$ (/L2) subscripted (/superscripted) correspond to inward (/outward) coordinations): i) $\mathrm{Zn}(\mathrm{OAc})_{2}$ or $\mathrm{Zn}(\mathrm{OTf})_{2} / \mathrm{BocProOH}$, DIPEA, $\mathrm{CDCl}_{3} / \mathrm{CD}_{3} \mathrm{OD} 9: 1$; ii) $\mathrm{BuNH}_{2}$ or $\mathrm{MBA}$; iii) $\mathrm{Boc}_{2} \mathrm{O}$. Inset: different combinations of $\mathrm{L}_{1} / \mathrm{L}_{2}$ used in this study.

a dipyrrin site, with two free coordination sites for the binding of two exogenous ligands: a carboxylato $\left(L_{1}\right)$ oriented inward, and an amino $\left(\mathrm{L}_{2}\right)$ oriented outward.11g for this study, we envisioned to control the chirality transfers from $L_{1}$ or $L_{2}$ by simple addition and protection of the amino ligand $L_{2}$, triggering

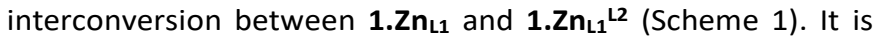
worth to note that these metal complexes exhibit hindered rotation of the 2-acetamidophenyl meso substituents, and thus correspond to dynamic mixtures of atropisomers (ESI). ${ }^{11 \mathrm{~g}}$

We chose to investigate two opposite situations depending on the external source of chirality, either the carboxylato $\left(L_{1}{ }^{*}\right)$ or the amino $\left(\mathrm{L}_{2}{ }^{*}\right)$ ligand. Based on previous results, Boc-protected proline $(\mathrm{BocProOH}, \mathrm{Boc}=$ ter-butyloxycarbonyl) and

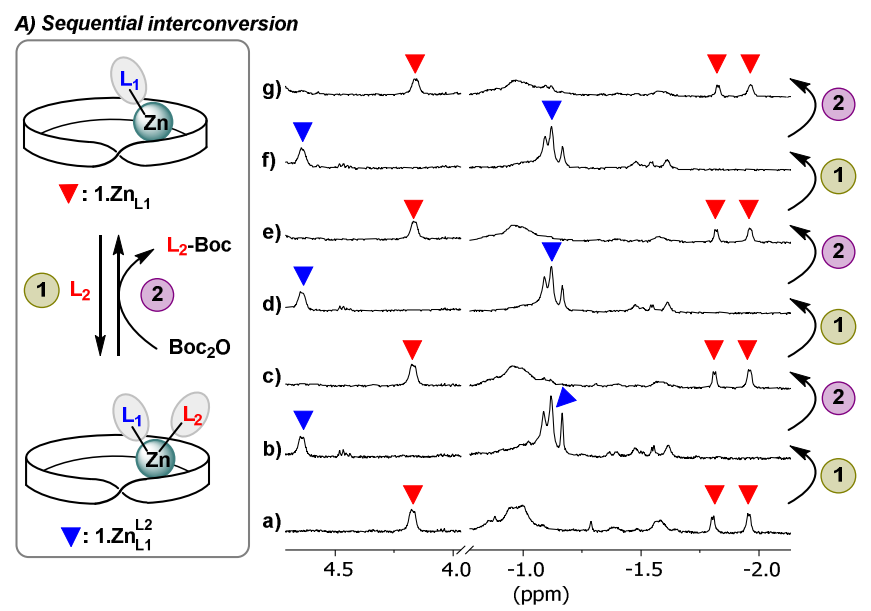

methylbenzylamine (MBA) were selected, with different $L_{1} / L_{2}$ combinations as detailed in Scheme 1 (inset and ESI). In order to make the amino function of $L_{2}$ no longer available, we decided to test a classical Boc protection reaction since it generally occurs in mild conditions and tolerates well other functionalities. ${ }^{13}$ Prior to chiral ligands, the reaction conditions were optimized with the simple case of $L_{1} / L_{2}$ corresponding to $\mathrm{AcO}^{-} / \mathrm{BuNH}_{2}$. All experiments were conducted in NMR tubes, in 9:1 $\mathrm{CDCl}_{3} / \mathrm{CD}_{3} \mathrm{OD}$ solutions at ca. $4 \mathrm{mM}$ concentration.

Thus, 1. $\mathrm{Zn}_{\mathrm{OAC}}{ }^{\mathrm{NH} 2 \mathrm{Bu}}$ (Scheme 1) was formed upon mixing 1, $\mathrm{Zn}(\mathrm{OAc})_{2}$ (1.5 eq.), $\mathrm{BuNH}_{2}$ (5 eq.) in the presence of DIPEA (5 eq., DIPEA = diisopropylamine), and subjected to reaction with different amounts of $\mathrm{Boc}_{2} \mathrm{O}\left(1,1.5\right.$ and 4 eq. relative to $\left.\mathrm{BuNH}_{2}\right)$, leading to the following observations (ESI):

(i) The Boc protection is selective of the amino function of $\mathrm{BuNH}_{2}$, proceeds cleanly, and gives back effectively $1 . \mathbf{Z n}_{\mathrm{OAc}}$ along with the formation of BuNHBoc and $t \mathrm{BuOH} ;{ }^{14}$

(ii) With 1 eq. of $\mathrm{Boc}_{2} \mathrm{O}$ relative to $\mathrm{BuNH}_{2}$, the Boc protection processes slowly and is not completed after 5 hours at room temperature (RT). Heating at $50{ }^{\circ} \mathrm{C}$ fastens the reaction, but ${ }^{1} \mathrm{H}$ NMR shows a new complex set of signals in the "non-aromatic" region (6-6.5 ppm), likely corresponding to hexaphyrin degradation;

(iii) Using 1.5 eq. of $\mathrm{Boc}_{2} \mathrm{O}$ relative to $\mathrm{BuNH}_{2}$, a more convenient reaction time of $c a .2$ hours at RT is needed to achieve a complete backward process. Note that without neither hexaphyrin nor $\mathrm{Zn}(\mathrm{II})$, these conditions lead to a much faster formation of BuNHBoc ( $<15 \mathrm{~min}$ ), indicating a decreased reactivity of the coordinated $\mathrm{BuNH}_{2}$ in $1 . \mathrm{Zn}_{\mathrm{OAc}}{ }^{\mathrm{NH2Bu}}$;

(iv) Complex $1 . \mathrm{Zn}_{\mathrm{OAc}}$ tolerates well a large excess of $\mathrm{Boc}_{2} \mathrm{O}(20$ eq., i.e. 4 eq. relative to $\mathrm{BuNH}_{2}$ ), the reaction being complete after $c a .15$ min at RT.

These observations allowed us to define two strategies for multiple in situ interconversions between $1 . \mathrm{Zn}_{\mathrm{OAc}}$ and 1.Zn OAc $^{\mathrm{NH} 2 \mathrm{Bu}}$, proceeding either sequentially or in "one-step" (Figure $2 \mathrm{~A}$ and $\mathrm{B}$ ). For the first approach, 1.2n $\mathrm{OAc}^{\mathrm{NH2Bu}}$ was

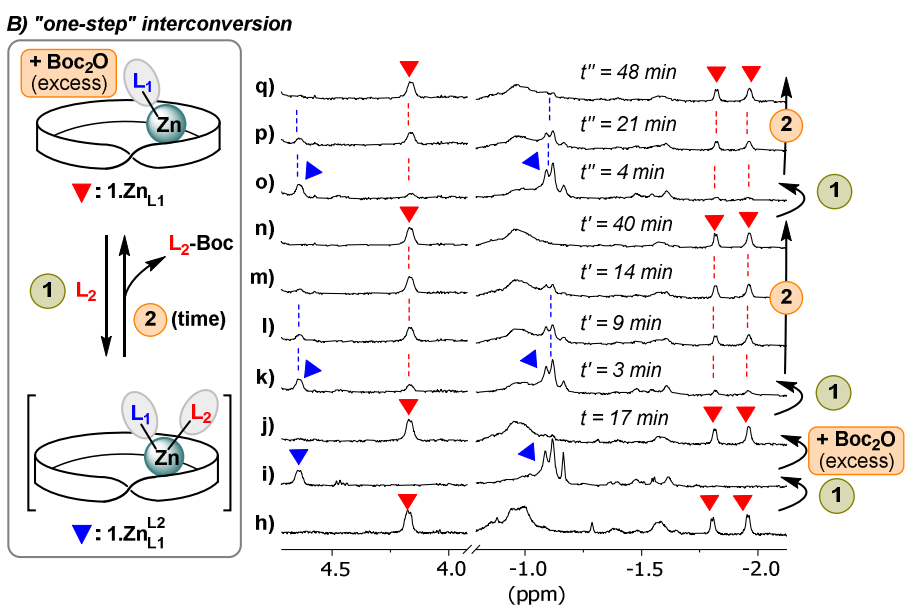

Figure 2. Partial ${ }^{1} \mathrm{H}$ NMR spectra $\left(\mathrm{CDCl}_{3} / \mathrm{CD}_{3} \mathrm{OD} 9: 1,298 \mathrm{~K}\right)$ related to the in situ interconversions between $1.2 \mathbf{n}_{\mathrm{L1}}$ and $1.2 \mathbf{n}_{\mathrm{L1}}{ }^{\mathrm{L} 2}\left(\mathrm{~L}_{1}=\mathrm{AcO} \text {, } \mathrm{L}_{2}=\mathrm{BuNH}\right)_{2}$. A): two-step process with sequential addition of forward and backward agents; $\mathrm{B}$ ): "one-step" process using a large excess of backward agent. Steps labelled " 1 " and " 2 " correspond to the addition of BuNH ${ }_{2}$ and the addition and/or reaction with $\mathrm{Boc}_{2} \mathrm{O}$, respectively (ESI). Highlighted signals at 4.64 and $4.16 \mathrm{ppm}$ (broad doublets) correspond to an ortho aromatic proton of a meso 2acetamidophenyl group oriented inward, those at $c a .-1.12 \mathrm{ppm}$ (three singlets) to bound AcO- ligands ( $\mathrm{L}_{1}$ ) oriented inward, and those at -1.80 and $-1.96 \mathrm{ppm}$ (broad doublets) to inner $\beta$-pyrrolic protons (ESI). ${ }^{11 g}$ 
generated from $1.2 n_{\text {OAc }}$ (Figure $2 \mathrm{~b}$, blue triangles) then allowed to react for $c a .2 \mathrm{~h}$ at RT with 7 eq. of $\mathrm{Boc}_{2} \mathrm{O}$, giving back $1.2 \mathrm{n}_{\mathrm{OAc}}$ (Figure 2c, red triangles). Second and third interconversions were achieved upon two successive additions of 7 eq. of $\mathrm{BuNH}_{2}$ and 7 eq. of $\mathrm{Boc}_{2} \mathrm{O}$, with moderate fatigability (Figure $2 \mathrm{~d}-\mathrm{g}$ ). ${ }^{14}$ In the second approach, $1 . \mathrm{Zn}_{\mathrm{OAc}}{ }^{\mathrm{NH2Bu}}$ (Figure $2 \mathrm{i}$, blue triangles) reacted with 20 eq. of $\mathrm{Boc}_{2} \mathrm{O}$, rapidly giving back $1.2 n_{\text {OAc }}$ (Figure $2 \mathrm{j}$, red triangles). Once done, 15 eq. of $\mathrm{Boc}_{2} \mathrm{O}$ remain in solution. Then 5 eq. of $\mathrm{BuNH}_{2}$ were added, and a ${ }^{1} \mathrm{H}$ NMR spectrum was immediately recorded (Figure $2 \mathrm{k}, 3 \mathrm{~min}$ after addition). It showed $1.2 n_{O A C}{ }^{\mathrm{NH2Bu}}$ as major species together with traces of 1.Zn $\mathrm{OAc}$, and conversion of the former complex to the latter one rapidly took place (Figure $2 \mathrm{I}-\mathrm{n}, 9$ to $40 \mathrm{~min}$ after addition of $\mathrm{BuNH}_{2}$ ). At this point, 10 eq. of $\mathrm{Boc}_{2} \mathrm{O}$ remain in solution. Then, 5 other equivalents of $\mathrm{BuNH}_{2}$ were added, leading again to the rapid formation and subsequent consumption of $1.2 n_{O A C}{ }^{\mathrm{NH} 2 \mathrm{Bu}}$ (Figure 2o-q). Thus, according to these two approaches, 1.Zn OAc ${ }^{\mathrm{NH} 2 \mathrm{Bu}}$ was generated either as a stable or transient species. ${ }^{15}$ Remarkably, in approach B, a second set of three additional interconversions was achieved in situ upon "refilling the tank" with 15 eq. of $\mathrm{Boc}_{2} \mathrm{O}$ followed by three successive additions of 5 eq. of $\mathrm{BuNH}_{2}$, leading in total to six interconversions (ESI). ${ }^{14}$

In the next step, we focused on the two complexes $1 . \mathbf{Z n}_{\mathbf{L 1}}{ }^{\mathbf{L 2}}$ with $\mathrm{L}_{1} / \mathrm{L}_{2}=$ BocProO/BuNH $\mathrm{H}_{2}$ and $\mathrm{AcO} / \mathrm{MBA}$. The first situation, with the chiral source supplied by the carboxylato ligand, exhibits a positive cooperativity between the two ligands $L_{1} *$ and $L_{2}$ : without $\mathrm{BuNH}_{2}\left(\mathrm{~L}_{2}\right)$, what is named $\mathbf{1}$. $\mathbf{Z n}_{\mathrm{L1}}$ for simplicity reasons, corresponds to an ill-defined mixture of complexes, with only partial binding of BocProO- $\left(\mathrm{L}_{1}^{*}\right)$ in line with a higher steric hindrance than AcO- (see ref $11 \mathrm{~g}$ ). However, upon addition of amino ligand $L_{2}$, a well-defined mixture is produced (two major species readily identified by ${ }^{1} \mathrm{H}$ NMR analysis, see ref $11 \mathrm{~g}$ ), with $\mathrm{Zn}(\mathrm{II})$-bound $\mathrm{L}_{2}$ and $\mathrm{L}_{1}$ * oriented outward and towards the Möbius ring (Scheme 1), respectively. Therefore, the transfer of chirality is more effective in the presence of $L_{2}$, resulting in almost a three fold enhancement of the electronic circular dichroism (ECD) intensity (Figure 3a, blue vs red plain line, $\mathrm{L}_{1}{ }^{*}=$ $(S) B$ ocProO-). ${ }^{16}$ In this case, the negative bisignate Cotton effects $\left(\lambda_{\max }=632 / 624 \mathrm{~nm}\right)$ indicate that both $1.2 \mathrm{n}_{\mathrm{L1}}$ and $1 . \mathrm{Zn}_{\mathrm{L1}}{ }^{\mathrm{L2}}$ adopt a preferential $M$ twist (left-handed helicity), ${ }^{11 \mathrm{f}}$ but with different magnitude.

Upon Boc protection of $\mathrm{L}_{2}$ according to the above-described strategy " $A$ " (Figure 3 inset, see the ESI for ${ }^{1} \mathrm{H}$ NMR studies), the

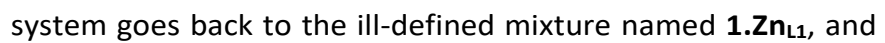
the initial ECD signal is restored (Figure 3a, red dashed line). This interconversion corresponds to a reversible amplification phenomenon, the two chiral states having, at a given wavelength, ECD values of same signs but of different intensities. Although the system shows an obvious fatigability, in situ interconversion between those two states was realized

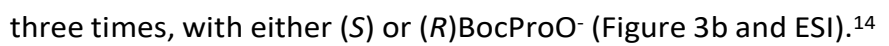
It is worth to note that herein, the amino ligand acts as an achiral effector ${ }^{11 c, f, g}$ that regulates the transfer of chirality to the twisted $\pi$-system by enhancing $\mathrm{Zn}$ (II)-binding of the external source of chirality, which is somehow reminiscent of allosteric modes of regulation in enzymes. ${ }^{17}$
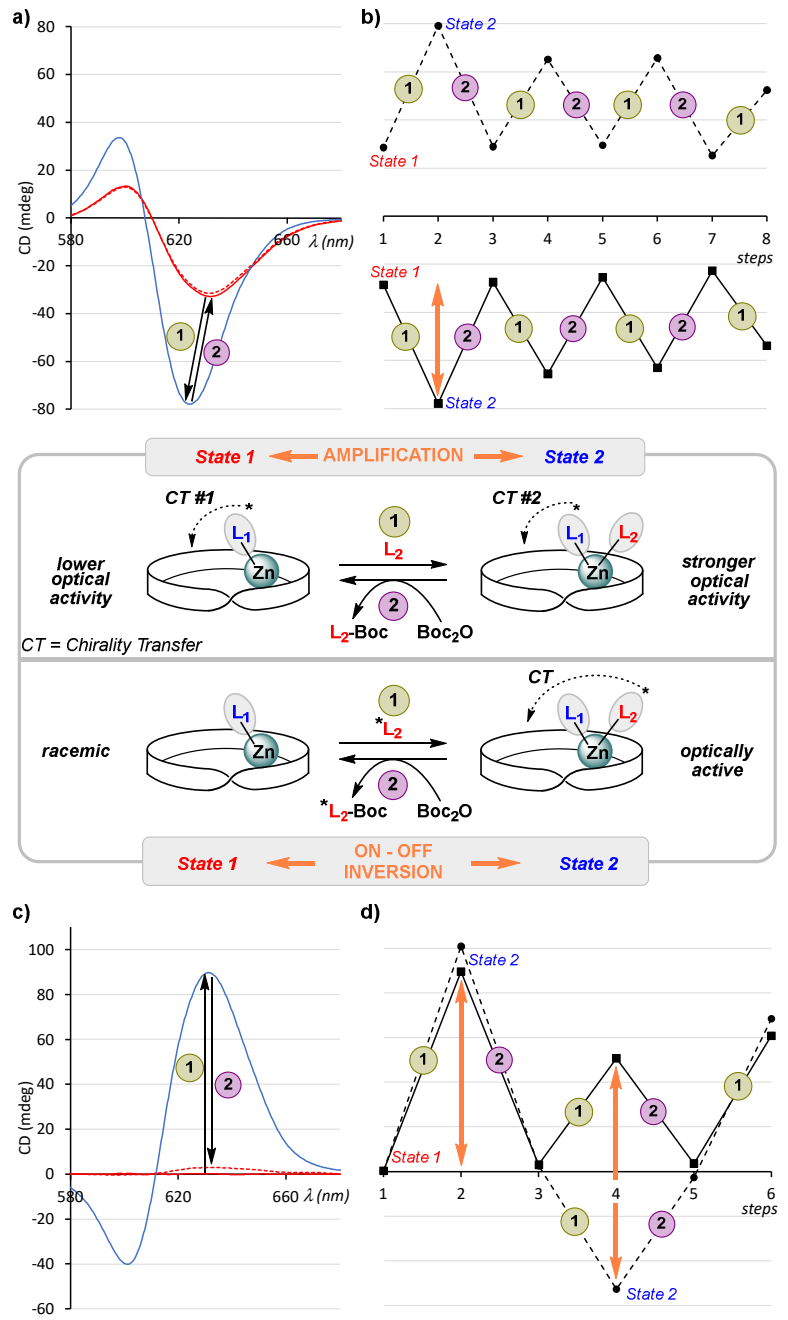

Figure 3. Changes in ECD spectra $\left(\mathrm{CHCl}_{3} / \mathrm{CH}_{3} \mathrm{OH}\right.$ 9:1) related to $1.2 \mathbf{n}_{\mathrm{L} 1} / \mathbf{1} \cdot \mathbf{Z n}_{\mathrm{L1}}{ }^{12}$ interconversions, with the source of chirality supplied either by $L_{1}$ [upper part, $L_{1}{ }^{*}=(S)$ or $(R)$ BocProO $^{-}$and $\mathrm{L}_{2}=\mathrm{BuNH}_{2}$ ] or $\mathrm{L}_{2}$ [lower part, $\mathrm{L}_{1}=\mathrm{AcO}^{-}$and $\mathrm{L}_{2}{ }^{*}=(S)$ or $(R) \mathrm{MBA}$ ]: a) amplification phenomenon owing to the cooperative $\mathrm{Zn}(\mathrm{II})$-binding of $\mathrm{L}_{1}{ }^{*}$ and $\mathrm{L}_{2}$, that drives the efficiency of the transfer of chirality to the Möbius ring; b) changes in ECD values at $624 \mathrm{~nm}$ when three transformation cycles were run, with $L_{1}{ }^{*}$ of opposite configuration [dashed/plain lines: $\mathrm{L}_{1}{ }^{*}=(R) /(S)$ BocProO-]; ) on-off phenomenon lying on the addition and protection of the chiral source $L_{2}^{*}\left[L_{2}^{*}=(S) M B A\right]$; d) changes in ECD values at $632 \mathrm{~nm}$ illustrating an inversion phenomenon upon addition of $\mathrm{L}_{2}{ }^{*}$ of opposite configuration $\left[\mathrm{L}_{2}{ }^{*}=(S) \mathrm{MBA}\right.$ except in step $3->4$, dashed line, $\left.\mathrm{L}_{2} *=(R) \mathrm{MBA}\right]$.

The second situation, with the chiral source supplied by the amino ligand, behaves differently although it also shows positive cooperativity. Indeed, whereas small size ligand AcO$\left(L_{1}\right)$ binds to $Z n(I I)$ without $L_{2}{ }^{*}$, the presence of $L_{1}$ is mandatory for the binding of $\mathrm{L}_{2}{ }^{*}$ (MBA) to $\mathrm{Zn}$ (II) (a putative complex "1.Zn $\mathrm{n}_{\mathrm{L2}}$ " has never been observed). [11g] In ECD spectroscopy, 1.Zn $n_{\text {OAc }}$ is silent (racemic) but shows an intense signal upon addition of $(S) M B A$, the positive bisignate Cotton effect $\left(\lambda_{\max }=\right.$ $632 \mathrm{~nm}$ ) indicating that $1.2 \mathrm{n}_{\mathrm{OAC}}{ }^{(\text {S)MBA }}$ preferentially adopts a $P$ twist (Figure 3c, blue line vs red plain line). ${ }^{11 f}$ The in situ Boc protection of the bulky (S)MBA (Figure 3 inset) revealed more difficult than for $\mathrm{BuNH}_{2}$ and, in order to maintain reasonable reaction times, the above-described approach $B$ was applied. However, in that case, a large excess of $\mathrm{Boc}_{2} \mathrm{O}$ ( 20 eq.) had to be kept constant to complete the backward process, the 


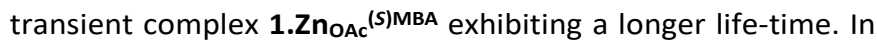
optimized conditions, this interconversion between $1.2 n_{O A c}$ and 1.Zn OAC $^{(S) M B A}$ was realized four times $\left({ }^{1} \mathrm{H}\right.$ NMR experiments, ESI). ${ }^{14}$ As a result of the Boc protection of (S)MBA, an almost complete disappearance of the ECD signal was observed (Figure $3 c$, red dashed line), the forth and back process corresponding to an on-off chiroptical phenomenon different from the amplification one of Figure 3a. Note that a lower ECD intensity is reached for "state 2 " of the second interconversion process (Figure $3 d$, plain line, step 4), due to the transient nature of

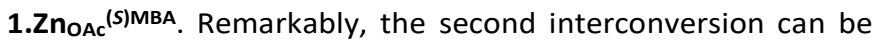
realized with $L_{2}$ * of opposite configuration, i.e. with $(R) \mathrm{MBA}$, leading to a reverse preferential twisting of the $\pi$-system $\left(1 . \mathrm{n}_{\mathrm{OAC}}{ }^{(R) M B A}: M\right.$ twist favored), as inferred from the ECD values of opposite signs (Figure 3d, dashed vs plain lines, step 4). This particular situation thus generates a chiroptical inversion phenomenon, and several ECD sign inversions were realized in situ upon sequential additions/removals of stereogenic sources of opposite configuration (Figure 3d, dashed line, steps 2, 4, 6: $M$ twist favored $\rightarrow P$ twist favored $\rightarrow M$ twist favored). To the best of our knowledge, interconverting at will the $P / M$ twist of a Möbius $\pi$-conjugated system is unprecedented.

In conclusion, the dynamic nature of the Möbius aromatic $\pi$ system of 1 was successfully harnessed evidencing different chiroptical regulation phenomena: amplification, on-off, inversion. The unique $\mathrm{Zn}$ (II) coordination behavior of $\mathbf{1}$ featuring selective and cooperative ligand-metal binding processes under thermodynamic control, associated to an in situ protection sequence, allows to choose and tune the role of the ligands (chirality supplier or achiral effector), and thus to play with chirality transfers at work. The particular Möbius [28] hexaphyrin scaffold therefore provides an interesting chiral switchable unit, which strongly deserves to be further investigated in sensing systems and catalysis. More robust Möbius [28] hexaphyrin switches with various modes of control (light, redox), exhibiting a single species for a given ECD state, are currently being studied in our laboratory.

\section{Notes and references}

1 (a) B. L. Feringa, R. A. van Delden, N. Koumura and E. M. Geertsema, Chem. Rev., 2000, 100, 1789; (b) J. W. Canary, Chem. Soc. Rev., 2009, 38, 747; (c) J. W. Canary, S. Mortezaei and J. Liang, Coord. Chem. Rev., 2010, 254, 2249; (d) Z. Dai, J. Lee and W. Zhang, Molecules, 2012, 17, 1247; (e) L. Zhang, H.-X. Wang, S. Li and M. Liu, Chem. Soc. Rev., 2020, 49, 9095.

2 S. F. Pizzolato, P. Štacko, J. C. M. Kistemaker, T. van Leeuwen and B. L. Feringa, Nature Catalysis, 2020, 3, 488.

3 (a) H. S. Rzepa, Chem. Rev., 2005, 105, 3697; (b) R. Herges, Chem. Rev., 2006, 106, 4820.

4 T. Mori, T. Tanaka, T. Higashino, K. Yoshida and A. Osuka, J. Phys. Chem. A, 2016, 120, 4241.

5 E. Heilbronner, Tetrahedron Lett., 1964, 5, 1923.

6 (a) D. M. Walba, M. Richards and R. C. Haltiwanger, J. Am. Chem. Soc., 1982, 104, 3219; (b) D. Ajami, O. Oeckler, A. Simon and R. Herges, Nature, 2003, 426, 819.

7 Y. Tanaka, S. Saito, S. Mori, N. Aratani, H. Shinokubo, N. Shibata, Y. Higuchi, Z. Yoon, K. Kim, S. Noh, J. Park, D. Kim and A. Osuka, Angew. Chem. Int. Ed., 2008, 47, 681.
8 For recent reviews, see: (a) T. Tanaka and A. Osuka, Chem. Rev., 2017, 117, 2584; (b) Y. Mo Sung, J. Oh, W.-Y. Cha, W. Kim, J. Min Lim, M.-C. Yoon and D. Kim, Chem. Rev., 2017, 117, 2257; (c) B. Szyszko, M. J. Białek, E. Pacholska-Dudziak and L. Latos-Grażyński, Chem. Rev., 2017, 117, 2839.

9 Selected leading references for Möbius hexaphyrins: (a) M. Stępień, L. Latos-Grażyński, N. Sprutta, P. Chwalisz and L. Szterenberg, Angew. Chem. Int. Ed., 2007, 46, 7869; (b) J. Sankar, S. Mori, S. Saito, H. Rath, M. Suzuki, Y. Inokuma, H. Shinokubo, K. S. Kim, Z. S. Yoon, J.-Y. Shin, J. M. Lim, Y. Matsuzaki, O. Matsushita, A. Muranaka, N. Kobayashi, D. Kim and A. Osuka, J. Am. Chem. Soc., 2008, 130, 13568; (c) T. Tanaka, T. Sugita, S. Tokuji, S. Saito and A. Osuka, Angew. Chem. Int. Ed., 2010, 49, 6619; (d) T. Higashino, J. M. Lim, T. Miura, S. Saito, J.-Y. Shin, D. Kim and A. Osuka, Angew. Chem. Int. Ed., 2010, 49, 4950.

10 An energy barrier of $c a .8 \mathrm{kcal}^{\mathrm{mol}} \mathrm{m}^{-1}$ was calculated for the benchmark meso-hexakis(pentafluorophenyl)[28] hexaphyrin, see: K. S. Kim, Z. S. Yoon, A. B. Ricks, J.-Y. Shin, S. Mori, J. Sankar, S. Saito, Y. M. Jung, M. R. Wasielewski, A. Osuka and D. Kim, J. Phys. Chem. A, 2009, 113, 4498.

11 (a) M. Ménand, M. Sollogoub, B. Boitrel and S. Le Gac, Angew. Chem. Int. Ed., 2016, 55, 297; (b) S. Le Gac, B. Boitrel, M. Sollogoub and M. Ménand, Chem. Commun., 2016, 52, 9347; (c) H. Ruffin, G. Nyame Mendendy Boussambe, T. Roisnel, V. Dorcet, B. Boitrel and S. Le Gac, J. Am. Chem. Soc., 2017, 139, 13847; (d) M. Ménand, M. Sollogoub, B. Boitrel and S. Le Gac, Chem. Eur. J., 2018, 24, 5804; (e) S. Le Gac, E. Caytan, V. Dorcet and B. Boitrel, Org. Biomol. Chem., 2019, 17, 3718; (f) R. Benchouaia, N. Cissé, B. Boitrel, M. Sollogoub, S. Le Gac and M. Ménand, J. Am. Chem. Soc., 2019, 141, 11583; (g) B. Boitrel and S. Le Gac, Chem. Commun., 2020, 56, 9166.

12 Chiroptical properties of singly/doubly twisted expanded porphyrins: (a) E. Vogel, M. Bröring, J. Fink, D. Rosen, H. Schmickler, J. Lex, W. K. K. Chan, Y.-D. Wu, D. A. Plattner, M. Nendel and K. N. Houk, Angew. Chem. Int. Ed., 1995, 34, 2511; (b) J. M. Lintuluoto, K. Nakayama and J.-i. Setsune, Chem. Commun., 2006, 3492; (c) J.-i. Setsune, A. Tsukajima, N. Okazaki, J. M. Lintuluoto and M. Lintuluoto, Angew. Chem. Int. Ed., 2009, 48, 771; (d) M. Izawa, T. Kim, S. Ishida, T. Tanaka, T. Mori, D. Kim and A. Osuka, Angew. Chem. Int. Ed., 2017, 56, 3982; (e) W. Naito, K. Urakawa, R. Sato, Y. Shigeta, N. Yasuda and H. Maeda, Org. Biomol. Chem., 2019, 17, 1163; (f) M. Izawa, T. Suito, S. Ishida, D. Shimizu, T. Tanaka, T. Mori and A. Osuka, Chem. Asian J., 2020, 15, 1440; (g) B. Basumatary, K. Mitsuno, M. Ishida and H. Furuta, J. Porphyrins Phthalocyanines, 2020, 24, 416. See also ref 4.

13 P. G. M. Wuts and T. W. Greene; Greene's Protective Groups in Organic Synthesis, $4^{\text {th }}$ Edition; 2007 John Wiley \& Sons, Inc.

14 The efficiencies of forward and backward processes are difficult to quantify, due to the dynamic nature of complexes $1 . Z n_{\mathrm{L} 1}$ and $1.2 n_{\mathrm{L1}}^{\mathrm{L2} 2}$, exhibiting multiple stereoisomers with complex sets of signals, partly broadened and overlapped. A decrease of the intensity of the ${ }^{1} \mathrm{H}$ NMR signals with the number of transformations is generally observed, which is expected for such a chemically triggered system based on labile $\mathrm{Zn}$ (II) complexes.

15 Molecular switches with forward and backward processes triggered by a single stimulus are challenging, see: A. Ghosh, I. Paul, M. Adlung, C. Wickleder and M. Schmittel, Org. Lett., 2018, 20, 1046.

16 Quantitative assessment of chirality transfer is hampered by the complexity of the ${ }^{1} \mathrm{H}$ NMR spectra. Indeed, diastereomers exhibiting opposite $P$ or $M$ twist cannot be differentiated from those featuring 2-acetamidophenyl atropisomerism.

17 L. Kovbasyuk and R. Krämer, Chem. Rev., 2004, 104, 3161. 